\title{
Synthesized Attributes of Water Use by Regional Vegetation: A Key to Cognition of "Water Pump" Viewpoint
}

\author{
Xin-hui Huang, ${ }^{1}$ Fu-ke Yu, ${ }^{2}$ Xiao-ying Li, ${ }^{1}$ Yuan Zheng, ${ }^{1}$ Hua Yuan, ${ }^{1}$ Jian-gang Ma, \\ Yan-xia Wang, ${ }^{1}$ Dan-hui Qi, ${ }^{1}$ and Hong-bo Shao ${ }^{3}$ \\ ${ }^{1}$ College of Environmental Science and Engineering, Southwest Forestry University, Kunming 650224, China \\ ${ }^{2}$ Institute of Environmental Sciences and Ecological Restoration, College of Ecology and Environmental Sciences, \\ Yunnan University, Kunming 650091, China \\ ${ }^{3}$ Key Laboratory of Coastal Biology \& Bioresources Utilization, Yantai Institute of Coastal Zone Research (YIC), \\ Chinese Academy of Sciences (CAS), Yantai 264003, China
}

Correspondence should be addressed to Fu-ke Yu; ylyfk2005@aliyun.com

Received 24 May 2014; Accepted 6 July 2014; Published 24 July 2014

Academic Editor: Marian Brestic

Copyright (C) 2014 Xin-hui Huang et al. This is an open access article distributed under the Creative Commons Attribution License, which permits unrestricted use, distribution, and reproduction in any medium, provided the original work is properly cited.

Recently, the frequent seasonal drought in Southwest China has brought considerable concerns and continuous heated arguments on the "water pump" viewpoint (i.e., the water demand from Hevea spp. and Eucalyptus spp. can be treated as a water pump) once again. However, such viewpoint just focused on water consumption from vegetation transpiration and its ecoenvironment impacts, which had not considered other attributes of vegetation, namely, water saving and drought resistance, and hydrological regulation (water conservation) into consideration. Thus, in this paper, the synthesized attributes of regional vegetation water use had been mainly discussed. The results showed that the study on such aspects as the characters of water consumption from vegetation transpiration, the potential of water saving and drought resistance, and the effects of hydrological regulation in Southwest China lagged far behind, let alone the report on synthesized attributes of water utilization with the organic combination of the three aspects above or the paralleled analysis. Accordingly, in this paper, the study on the synthesized attributes of water use by regional vegetation in Southwest China was suggested, and the objectives of such a special study were clarified, targeting the following aspects: (i) characters of water consumption from transpiration of regional typical artificial vegetation; (ii) potential of water saving and drought resistance of regional typical artificial vegetation; (iii) effects of hydrological regulation of regional typical artificial vegetation; (iv) synthesized attributes of water use by regional typical artificial vegetation. It is expected to provide a new idea for the scientific assessment on the regional vegetation ecoenvironment effects and theoretical guidance for the regional vegetation reconstruction and ecological restoration.

\section{Introduction}

In Southwest China, a global hot place for its abundant biodiversity and a place with frequent seasonal drought, an unprecedented transseasonal constant severe drought took place in 2010, which aroused considerable concerns in China and even worldwide $[1,2]$. Historically speaking, though several droughts broke in this area [3], the drought in 2010 was the severest with many socioeconomic losses and farreaching impacts $[3,4]$; in addition, since 2010 , droughts continuously took place in the following consecutive 4 years in such areas including Kunming, which had brought about public concerns at all social levels [5-7]. Accordingly, there were many scientific issues worth discussing behind the drought, among which the relationship between regional drought and regional artificial vegetation has become a scientific issue with rather considerable concerns recently [8].

In the past several decades, a great deal of artificial vegetation has been established targeting regional economic development and ecoenvironment protection in each province (autonomous region, municipality) in Southwest China. For example, the area of the land used for the plantation of Eucalyptus spp. in Guangxi, Yunnan, Guizhou, and the plantation of Hevea spp. in Yunnan have been considerably 
large. However, quite a few ecoenvironment problems have been brought by such artificial vegetation, such as the worsening of soil water and nutrition for the land $[9,10]$ and functional degradation of the ecosystem $[11,12]$ and decrease in biodiversity and land productivity $[13,14]$. The "water pump" viewpoint of $H$. spp. (E. spp.) prevailing in the past and the description of the cause of severe droughts in Southwest China as "a human disaster" prevailing in recent years were just in accordance with such ecoenvironment problems.

Undoubtedly, those in favor of "water pump" viewpoint did analyze ecoenvironment effects of regional typical artificial vegetation such as $H$. spp. and $E$. spp. from the standpoint of water consumption. However, the water ecological relationship of vegetation was not just limited to water consumption from transpiration; such attributes as water saving and drought resistance and hydrological regulation (water conservation) should also be included. Clearly, just to explore the ecoenvironment impacts of artificial vegetation from the perspective of water consumption was far from enough. Accordingly, it is suggested in this paper that only through the systematical analysis on the synthesized attributes of vegetation, including water consumption (transpiration), water saving (drought resistance), and water conservation (hydrological regulation), can the ecoenvironment effects of artificial vegetation be mastered comprehensively and further to objectively assess the relation between regional vegetation succession and regional drought.

Consequently, synthesized attributes of regional vegetation water use were mainly discussed in this paper, according to such research background above. Based on the all-round analysis on the status quo and development trends for characters of water consumption from vegetation transpiration, their potential of water saving and drought resistance, and their effects of hydrological regulation, a special study on the synthesized attributes of water use of typical artificial vegetation in Southwest China was suggested in this paper, in order to provide a new idea for the objective, scientific, and all-round assessment on the ecoenvironment effects of regional vegetation and further to provide a theoretical guidance for the reconstruction and recovery of regional vegetation, as well as a scientific cognition of the relationship between regional drought and regional artificial vegetation.

\section{Study Status Quo and Development Trends}

As mentioned above, vegetation water use includes three attributes: water consumption (transpiration), water saving (drought resistance), and water conservation (hydrological regulation), respectively, representing the direct water consumption from vegetation transpiration, vegetation selfadjustment to extreme moisture condition-drought stress, and its maintenance and regulation of such ecological hydrological conditions as rainfall, runoff, and soil water. The study status quo and development trends related to the topic in this paper would be illustrated in such three aspects above.

2.1. Water Consumption from Vegetation Transpiration. The character of water consumption from plant transpiration is one of the core ingredients in the study of plants' water physiology and ecology. Since the 21st century, quite a few scholars have conducted studies on water consumption from vegetation transpiration targeting regional vegetation construction and ecological restoration (Table 1). For example, Sui et al. [15] measured the daily transpiration rate of such commonly seen species in Loess Plateau regions as Forsythia suspense, Lonicera japonica, Rubus crataegifolius, and Swida alba. Xu et al. [16] discovered the laws of water consumption from vegetation transpiration of Haloxylon ammodendron in the hinterland of Taklimakan desert and the influential environment factors of stem sap flow. Wang et al. [17] analyzed the characteristics of daily, monthly, and seasonal changes in water consumption from transpiration of Magnolia liliiflora as a green species in Beijing City. Wang et al. [18] discovered the relationship between water consumption from transpiration and soil water of flue-cured tobacco species. Zhang et al. [19] studied the regulatory role of surface sand-covering in water consumption from transpiration of apple trees, and the list can go on $[20-25,40]$. Such findings illustrated that the study on water consumption from transpiration shifted to such synthesized studies as the analysis of its environmental influential factors, the development of large-scale research methods (e.g., scale transformation, model calculation, etc.), and the application of manmade regulation technologies (e.g., surface sand-covering, etc.) from the simple determination of transpiration rate (strength) of a single species, and the experimental species covered regional unique species for ecological recovery, landscape greening species, economic crops, horticultural plants, and so forth, and the study scale also extended to ecological system (e.g., forest stands) from individuals. However, through the comparative analysis of current literature, it is found that the study on water consumption from transpiration was still focused on species in arid or semiarid region, and the study on plants in other climatic province was rather weak. For example, as for the severe drought-stricken regions in Southwest China in 2010, the study on the characters of water consumption from transpiration of ecological recovery tree species in dry-hot river valley in Jinsha River [26] was the only report on such topic. Thus, such study status quo showed the double bottle-neck of deficiency in the basic theory and lack of technological methods that will hinder vegetation recovery and reconstruction in Southwest China and the prevention and treatment of such disaster as drought. Obviously, it is rather urgent to shift the study focus on water consumption from regional vegetation transpiration to the regions with uneven water resources and frequently drought-stricken areas.

\subsection{Potential of Water Saving and Drought Resistance of} Plants. The study on water saving and drought resistance of plants plays a significant scientific role in the agricultural and forestry development in arid and semiarid areas. In recent several years, the study on it at home and abroad gained a rapid growth in the following three aspects (Table 2): (i) the formation mechanisms of drought resistance and its influential factors. The recent related research results showed 


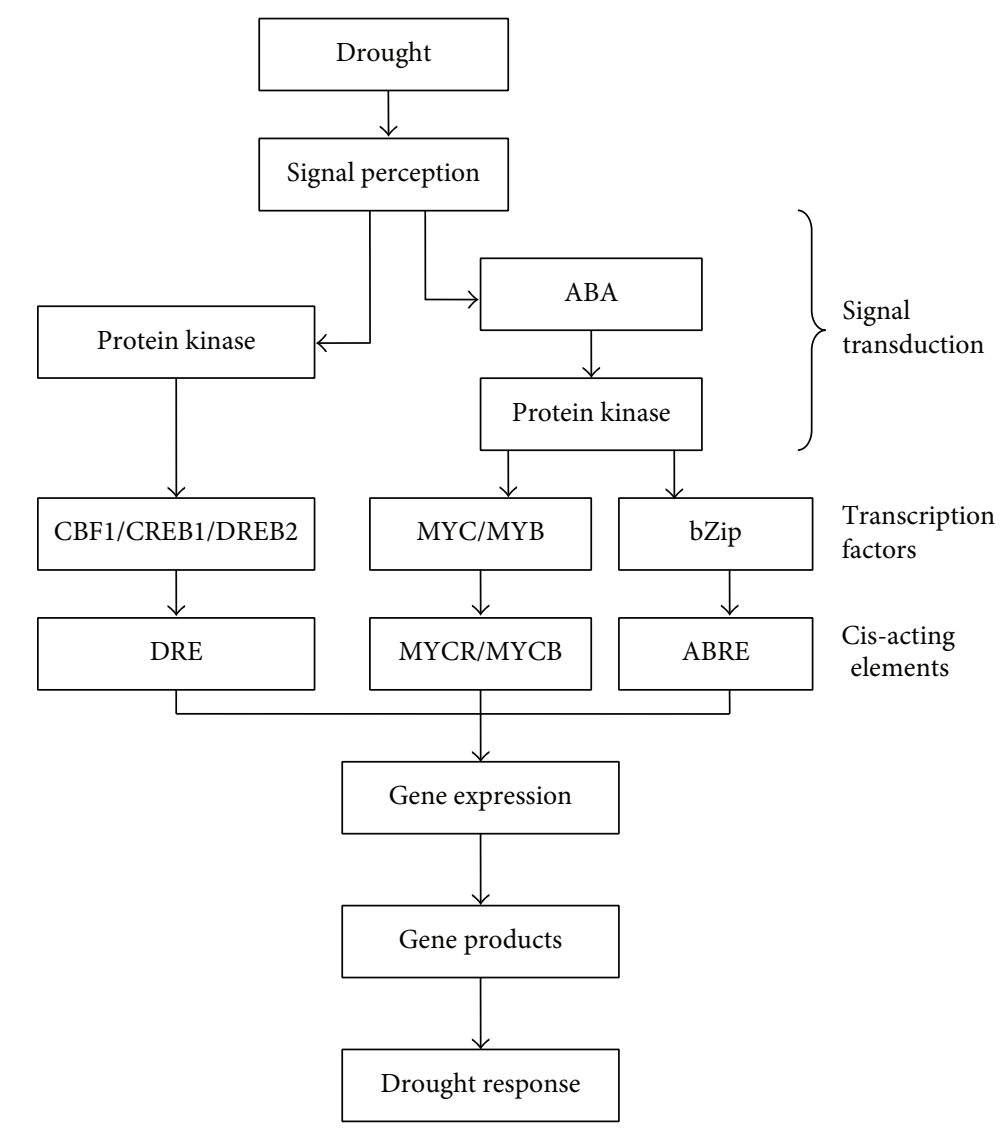

FIGURE 1: Signal transduction and gene expression in plant response to drought stress.

that there were many mechanisms, including ecological, morphological, anatomical, and physiological, and so forth, for the formation of drought resistance [27], and its influential factors included morphological adaptability characters, photosynthetic physiological index, the activity of oxidase, malondialdehyde (MDA) concentration, permeation regulation, hormone and stoma regulation, protein induced by drought, and stable carbon isotope[27]; (ii) the determination and assessment of drought-resisting capacities and the selection of drought-resisting species as well. Because of the complexity in the formation of drought-resisting mechanism and its influential factors, a single index could not meet the demand of scientific determination and comprehensive assessment of plants' drought-resisting capacities. Quite a few scholars had actively explored the assessment system and comprehensive assessment methods of multiple indexes for drought resistance of plants, and some rather good results had gained on such aspects as the selection of identification index for drought-resisting of some crops, the construction of comprehensive assessment system, the classification of drought-resisting capability of species, and the exploitation of drought-resisting species [28-31]. Accordingly, in some countries and regions, some regulations on drought-resisting identification and assessment were established for some main crops such as wheat, corn, and beans; (iii) the basis of artificial improvement and regulation for drought resistance. Presently, it is discovered that such methods as elimination of active oxygen inside the plants [32], accumulation of antioxidant substance [33], gene expression of drought response [34, 35], AM fungus inoculation [36], allogenic material implementation [37, 38], and drought hardening [39] can boost plants' drought resistance; such basic researches would provide strong scientific supports for R \& D of technologies used in artificial improvement and regulation of plants drought resistance. However, there were also some problems existing in the study of plants' drought resistance. For example, the study objects were focused mainly on major crops, horticultural plants, and grassland species in arid and semiarid areas, while the study on forest vegetation, especially ecological recovery trees and artificial economic trees, was far from abundant. Such problems had brought direct impacts on and potential threats to the regional forestry development and ecological recovery, which should be solved as soon and as early as possible.

It must be pointed out that the researches on droughtresistance mechanism of plants at molecular and cellular level sprang up consecutively in recent years.

Studies showed that when under the water stress, plants would make a positive response [41-46] via the transfer and transduction of intercellular and intracellular adverse signal [47-50], which indicated the rapid perception and positive adaptation of plants towards environmental changes. Such process includes the following 3 links: (i) perception of cells or organizations to water stress and production of intercellular 


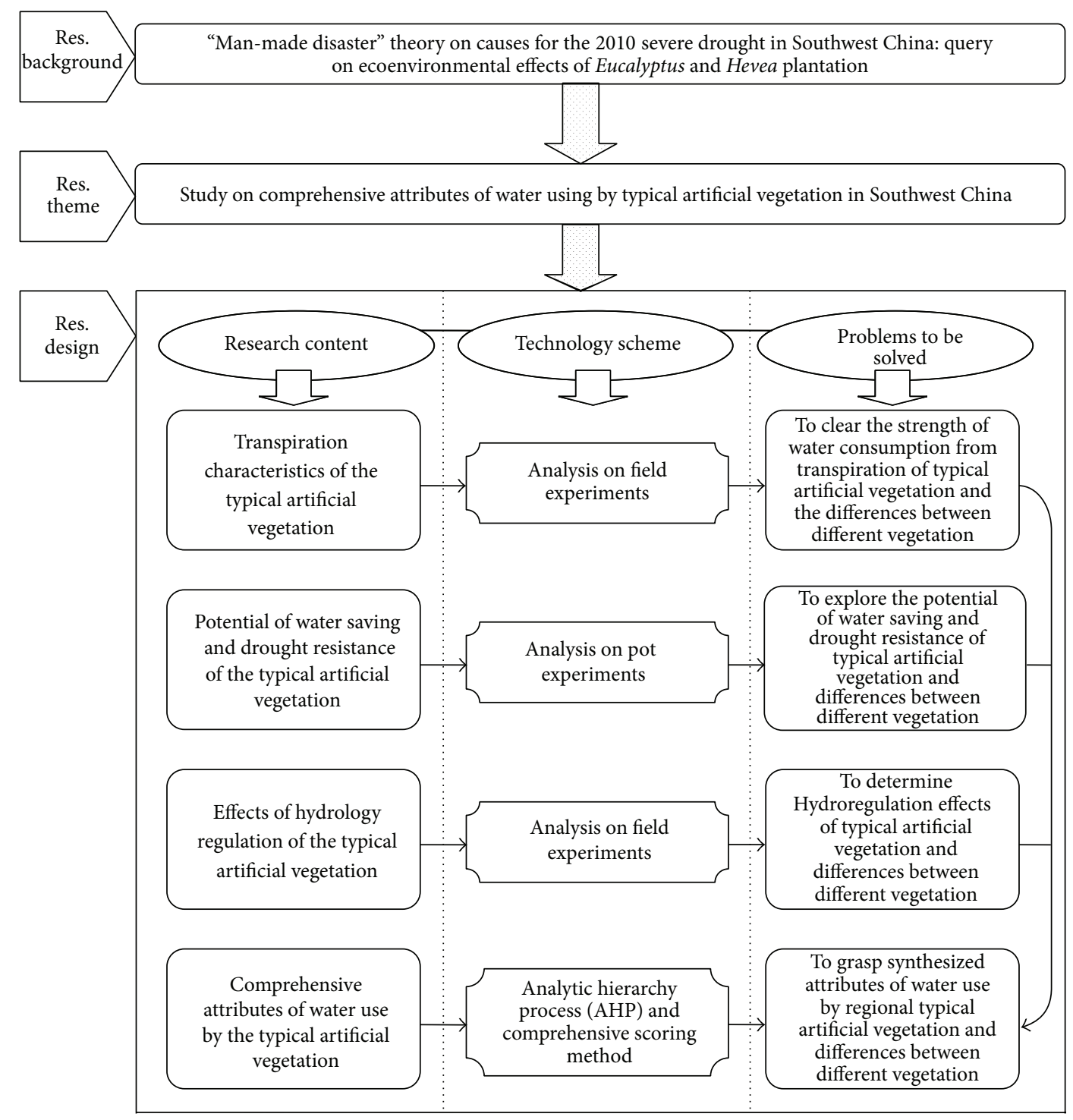

FIGURE 2: Technical route for synthesized research on water use by regional vegetation.

messengers afterwards; (ii) intercellular messengers transfer between cells or organizations and eventually arrive at the acting locus of the recipient cells; (iii) recognition, reception, transduction, and gene expression of recipient cells towards intercellular messengers, eventually leading to the physiological and functional optimization in cells; thus plants are characterized with the adaptation or resistance towards the stress [51].

\subsubsection{Perception and Recognition to Water Stress Signals.} There are diverse stress signals which can be perceived by cells or organizations [41, 43, 46, 52], including mechanical stress signals (plasmolysis of plants cells resulting from drought stress), osmotic stress signals (changes in transmembrane osmotic potential of plant cells resulting from water deficit), oxidative stress signals (production of free radical such as $\mathrm{H}_{2} \mathrm{O}_{2}, \mathrm{H}_{2} \mathrm{O}$ and active oxygen in plant chloroplast resulting from water stress), and defensive stress signals (changes in endogenous hormones of plant such as abscisic acid, ethylene, and polyamine resulting from drought stress); furthermore, the way such signals above are perceived and recognized is also characterized by diversity $[41,43,46,52]$.

2.2.2. Intracellular Transduction of Water Stress Signals. Intracellular transduction is a step-by-step process of signal transferring and amplifying via protein phosphorylation and dephosphorylation in plant. In this process, protein kinase is a key component. It has been found that quite a few protein kinases participated in the signals transduction of drought, mainly including CDPK (calcium-dependent protein kinase) [53] and MAPK (mitogen-activated protein kinase) [54].

2.2.3. Gene Expression Induced by Water Stress Signals. The perception and transduction to water stress signals activate a series of protein kinases, eventually leading to increase 
TABLE 1: Typical cases of study on transpiration characteristics of plant species.

\begin{tabular}{|c|c|c|c|}
\hline Study area & Subject investigated & Study method & Literature source \\
\hline Loess Plateau, China & $\begin{array}{l}\text { Forsythia suspense, Lonicera } \\
\text { japonica, Rubuscrataegifolius, and } \\
\text { Swida alba }\end{array}$ & Rapid weighing method & Sui et al. (2010) [15] \\
\hline $\begin{array}{l}\text { Hinterland of Taklimakan } \\
\text { desert, China }\end{array}$ & Haloxylonammodendron & Heat-balance technique & Xu et al. (2008) [16] \\
\hline Beijing City, China & Magnolia liliiflora & Thermal dissipation method & Wang et al. (2011) [17] \\
\hline Wuhan, China & Flue-cured tobacco & $\begin{array}{l}\text { Artificial water control experiment } \\
\text { in the shed of rain-free condition }\end{array}$ & Wang et al. (2007) [18] \\
\hline $\begin{array}{l}\text { Pingliang of Gansu Province, } \\
\text { China }\end{array}$ & Apple trees & Thermal diffusion method & Zhang et al. (2010) [19] \\
\hline $\begin{array}{l}\text { Hinterland of Taklimakan } \\
\text { desert, China }\end{array}$ & Calligonumarborescens & $\begin{array}{l}\text { By using heat-balance stem flow } \\
\text { gauge }\end{array}$ & Shan et al. (2012) [20] \\
\hline Urumqi of Xinjiang, China & Pinaceaeschrenkiana stands & $\begin{array}{l}\text { Thermal diffusion method and } \\
\text { Fitting function method }\end{array}$ & Zhang et al. (2011) [21] \\
\hline Miyazaki and Akita, Japan & Forest vegetation & Model analysis method & Komatsu et al. (2008) [22] \\
\hline Northwest China & $\begin{array}{l}\text { Caraganaintermedia, } \\
\text { Hippophaerhamnoides, Hedysarum } \\
\text { leave, and Salix psammophila }\end{array}$ & $\begin{array}{l}\text { By using porometer, leaf area meter, } \\
\text { and Mettler electronic balance } \\
\text { combined with calculation }\end{array}$ & Tong et al. (2008) [23] \\
\hline Southeastern Arizona, USA & $\begin{array}{l}\text { Eragrostislehmanniana, } \\
\text { Heteropogoncontortus }\end{array}$ & A chamber-based isotope method & Yepez et al. (2005) [24] \\
\hline $\begin{array}{l}\text { Central Sweden, Eastern } \\
\text { China, and Northwestern } \\
\text { Cyprus }\end{array}$ & Different climatic regions & Model analysis method & Xu and Singh (2005) [25] \\
\hline $\begin{array}{l}\text { Dry-hot valleys of the Jinsha } \\
\text { River in Yunnan, China }\end{array}$ & $\begin{array}{l}28 \text { potted afforestation species (e.g., } \\
\text { Ziziphusmauritiana, etc.) for } \\
\text { vegetation restoration }\end{array}$ & Rapid weighing method & Duan et al. (2009) [26] \\
\hline
\end{tabular}

in concentration and activity of related transcription factors and the combination with relevant cis-acting elements, to further induce gene expression. Such process falls into two pathways-ABA dependent pathway and ABA independent pathway $[50,55,56]$ (Figure 1).

Many plant genes can be induced to express via drought [57]. The genes induced to express can be divided into two categories according to functional ways-regulatory protein gene and functional protein gene [55]. The products coded by the former play a regulatory role in signal transduction and gene expression, such as transcription factors, and the products coded by the latter play a direct protecting role in the process of plant drought-resistance, mainly including key enzymes to compound osmotic regulatory materials, enzymes to eliminate active oxygen, and protein to protect biomacromolecule and cytomembrane structure [45].

2.3. Hydrological Regulation Effects of Vegetation. Hydrological regulation effects of vegetation play an irreplaceable role in maintaining regional ecological security and environment health. Recently, some rather influential achievements have been obtained in the scientific study of such field (Table 3). For example, in the study on Loess area, it is found that the change in land use pattern and vegetation spatial pattern would lead to differences in the runoff and sediment yield [58-60]; the analysis on the Picea crassifolia forest in Qilian Mountain, Qinghai, illustrated that the ecological hydrological indexes of forest stands such as total penetrated rainfalls, interception, and trunk stream were greatly influenced by canopy structural characteristics [61]; the study on the reservoir area of Three Gorges showed that the general ecological hydrological function of the forest ecosystem in the reservoir area was represented as shrub forest $>$ mixed conifer-broadleaf forest, evergreen broad-leaved forest $>$ Phyllostachys pubescens forest $>$ cropland, among which the ecological hydrological function of forest vegetation was 1.12 2.90 times of that of cropland, and the ecological hydrological function of shrub forest was the best [62], and the list could go on [63]. There were few reports on the ecological hydrological regulation effects of vegetation in Southwest China 10 years before $[64,65]$; several years afterwards, there was almost no report, though only in recent years the study on this issue got warm again after a cold spell [66-70]. However, from the general development status quo in such field at home and abroad, the study on the hydrological regulation effects of vegetation was characterized with regional imbalance; namely, it was mostly focused on vegetation in arid or semiarid area, while the study on vegetation in other climatic regions was rather deficient. Take Southwest China for example, there were few research projects approved on such theme recently and before, in addition to lack of link between research topics selected as well as achievements in series. Considering it from the perspective of regional environment health and 
TABLE 2: Typical cases of study on potential of water saving and drought-resistance of plant species.

\begin{tabular}{|c|c|c|c|}
\hline Research topic & Subject investigated & Study method & Literature source \\
\hline $\begin{array}{l}\text { Drought resistance (tolerance) } \\
\text { mechanism }\end{array}$ & Plant species in arid area of China & Comprehensive review method & Li et al. (2010) [27] \\
\hline $\begin{array}{l}\text { Drought resistance } \\
\text { identification and evaluation }\end{array}$ & $\begin{array}{l}\text { Backcross lines of Dongxiang } \\
\text { common wild rice } \\
\text { (Oryzarufipogon Griff.) }\end{array}$ & $\begin{array}{l}\text { Correlation analysis combined with } \\
\text { stepwise regression analysis }\end{array}$ & Fu et al. (2012) [28] \\
\hline $\begin{array}{l}\text { Drought resistance } \\
\text { identification and evaluation }\end{array}$ & $\begin{array}{l}\text { Different peanut varieties widely } \\
\text { grown in Northern China }\end{array}$ & $\begin{array}{l}\text { Drought coefficient method and } \\
\text { Subordinate function value method }\end{array}$ & Zhang et al. (2012) [29] \\
\hline $\begin{array}{l}\text { Drought resistance } \\
\text { identification and evaluation }\end{array}$ & Brassica napusL. & $\begin{array}{l}\text { Principal component analysis, } \\
\text { regression analysis, and clustering } \\
\text { analysis }\end{array}$ & Zhu et al. (2011) [30] \\
\hline $\begin{array}{l}\text { Drought resistance } \\
\text { identification and evaluation }\end{array}$ & Nine marigold cultivars & $\begin{array}{l}\text { Principal component analysis, } \\
\text { subordinate function, and cluster } \\
\text { analysis }\end{array}$ & Tian et al. (2011) [31] \\
\hline $\begin{array}{l}\text { Basis for drought resistance } \\
\text { regulation (improvement) }\end{array}$ & Crop plants & Comprehensive review method & Gill and Tuteja (2010) [32] \\
\hline $\begin{array}{l}\text { Basis for drought resistance } \\
\text { regulation (improvement) }\end{array}$ & Bread wheat (Triticumaestivum L.). & Correlation analysis method & Osipova et al. (2011) [33] \\
\hline $\begin{array}{l}\text { Basis for drought resistance } \\
\text { regulation (improvement) }\end{array}$ & Arabidopsis spp. & Vacuolar localization method & Wang et al. (2011) [34] \\
\hline $\begin{array}{l}\text { Basis for drought resistance } \\
\text { regulation (improvement) }\end{array}$ & $\begin{array}{l}\text { Transgenic tobacco } \\
\text { (Nicotianatabacum cv. Xanthi) } \\
\text { plants }\end{array}$ & $\begin{array}{l}\text { Technologies method of molecular } \\
\text { biology }\end{array}$ & Faize et al. (2011) [35] \\
\hline $\begin{array}{l}\text { Basis for drought resistance } \\
\text { regulation (improvement) }\end{array}$ & Trifoliumalexandrinum & $\begin{array}{l}\text { By using molecular biology } \\
\text { technologies }\end{array}$ & Zézé et al. (2008) [36] \\
\hline $\begin{array}{l}\text { Basis for drought resistance } \\
\text { regulation (improvement) }\end{array}$ & Haloxylonammodendron & $\begin{array}{l}\text { Completely randomized plot } \\
\text { experiment }\end{array}$ & Kang et al. (2012) [37] \\
\hline $\begin{array}{l}\text { Basis for drought resistance } \\
\text { regulation (improvement) }\end{array}$ & Arabidopsis thaliana & Isotopic tracer method & Ikegami et al. (2009) [38] \\
\hline $\begin{array}{l}\text { Basis for drought resistance } \\
\text { regulation (improvement) }\end{array}$ & $\begin{array}{l}\text { Two psammophytes (Setariaviridis } \\
\text { and Digitariaciliaris) }\end{array}$ & $\begin{array}{l}\text { Completely randomized plot } \\
\text { experiment }\end{array}$ & Luo et al. (2011) [39] \\
\hline
\end{tabular}

sustainable development, it is rather urgent to strengthen the study in this field.

From the analysis above, the scientific researches on water consumption from vegetation transpiration, water saving and drought resistance, and hydrological regulation effects have gained great achievements or a rapid growth recently. However, there was a regional imbalanced study in each field, especially in Southwest China, a place frequently stricken with seasonal droughts; the study in each field mentioned above developed slowly and lagged far behind. Furthermore, there was no report on the synthesized attributes of water use by vegetation from the standpoint of the comprehensive assessment based on the study with the paralleled analysis or organic combination of the three. Such study status quo has become a major barrier for the regional vegetation construction and ecological recovery as well as the development and utilization of related disciplines. Consequently, it is of great urgency to launch and strengthen the scientific study on such related disciplines.

\section{Research Suggestions and Major Targets}

Based on the research status quo and development trends at present, together with the strategic consideration and technical demands for the comprehensive analysis on the ecoenvironment effects of vegetation and scientific recognition of the cause of regional drought, it is suggested in this paper that a special project should be launched from the perspectives of water consumption from transpiration, water saving and drought resistance, and water conservation to conduct a special research on synthesized attributes of water use by regional vegetation. Such project meets the strategic goal and technological demands of national and regional ecoenvironment protection, which was expected to provide scientific evidences and theoretic supports for the regional vegetation construction and ecological restoration together with the scientific cognition of the relationship between regional drought and regional artificial vegetation. Thus the major targets and key research contents are as follows.

(i) Characteristics of Water Consumption from Transpiration by Regional Typical Artificial Vegetation. Based on the selection of research regions and typical artificial vegetation, together with field experiments, such characters of 
TABLE 3: Typical cases of study on hydrological regulation effect of vegetation.

\begin{tabular}{|c|c|c|c|}
\hline Study area & Subject investigated & Study method & Literature source \\
\hline Loess Plateau, China & Slope with different land use pattern & Field plot experiment & She et al. (2011) [58] \\
\hline Loess Plateau, China & Five different land use types & Field plot experiment & She et al. (2010) [59] \\
\hline $\begin{array}{l}\text { Menglun, Xishuangbanna, } \\
\text { Southwest China }\end{array}$ & $\begin{array}{l}\text { Ten land use categories in the study } \\
\text { area }\end{array}$ & By using RS and GIS technology & Hu et al. (2009) [60] \\
\hline the Qilian Mountains, China & $\begin{array}{l}\text { Qinghai spruce (Piceacrassifolia) } \\
\text { forest }\end{array}$ & Field observation experiment & Tian et al. (2012) [61] \\
\hline $\begin{array}{l}\text { Three Gorges Reservoir area, } \\
\text { China }\end{array}$ & $\begin{array}{l}5 \text { typical vegetation types (mixed } \\
\text { conifer and broadleaf forest, } \\
\text { evergreen broadleaved forest, etc.) }\end{array}$ & $\begin{array}{l}\text { Analytic hierarchy process (AHP) } \\
\text { and comprehensive scoring method }\end{array}$ & $\begin{array}{l}\text { Y. Q. Wang and Y. J. Wang } \\
(2010)[62]\end{array}$ \\
\hline - & Forest ecosystems & Comprehensive review method & Neary et al. (2009) [63] \\
\hline $\begin{array}{l}\text { Xishuangbanna, Southwest } \\
\text { China }\end{array}$ & $\begin{array}{l}\text { Tropical seasonal rain forest and } \\
\text { rubber forest }\end{array}$ & Water balance method & Zhang et al. (2003) [64] \\
\hline Central Yunnan, China & $\begin{array}{l}\text { Pinusyunnanesis plantation, } \\
\text { Eucalyptus maidenii plantation, and } \\
\text { their mixed plantation }\end{array}$ & $\begin{array}{l}\text { Field observation combined with } \\
\text { sampling and analysis }\end{array}$ & Wang et al. (2001) [65] \\
\hline $\begin{array}{l}\text { Ailao Mountain, Yunnan, } \\
\text { China }\end{array}$ & Evergreen broadleaf forest & $\begin{array}{l}\text { Field observation combined with } \\
\text { sampling and analysis }\end{array}$ & Qi et al. (2012) [66] \\
\hline $\begin{array}{l}\text { Xishuangbanna, Southwest } \\
\text { China }\end{array}$ & $\begin{array}{l}\text { Native tropical rain forest and } \\
\text { artificial rubber plantation }\end{array}$ & Isotopic tracer method & Liu et al. (2011) [67] \\
\hline Central Yunnan, China & $\begin{array}{l}\text { Eucalyptus plantation, Pinus } \\
\text { plantation, shrubland, and } \\
\text { seminatural and natural secondary } \\
\text { forests. }\end{array}$ & $\begin{array}{l}\text { Field observation combined with } \\
\text { sampling and analysis }\end{array}$ & Hou et al. (2010) [68] \\
\hline $\begin{array}{l}\text { Xishuangbanna, Southwest } \\
\text { China }\end{array}$ & $\begin{array}{l}\text { Tropical rain forest and rubber } \\
\text { plantation }\end{array}$ & Isotopic tracer method & Liu et al. (2008) [69] \\
\hline
\end{tabular}

regional typical vegetation as stem sap flow density, water consumption from transpiration, characters of daily and seasonal change, and influential environment factors were studied, to reveal the water consumption strength of typical artificial vegetation as well as its temporal-spatial characters and further to clear the interspecies differences of different vegetation species in water consumption from transpiration (Figure 2).

(ii) Potential of Water Saving and Drought Resistance of Regional Typical Artificial Vegetation. A test study flat should be established with pot experiments as the dominance, to study the characters of morphological and physiological changes of typical artificial vegetation species under the stress of drought and to explore its response mechanism and adaptability strategy towards the stress of drought, and further to clear the potential of water saving and drought resistance of typical artificial vegetation and the interspecies differences in such attributes based on the selection of identification index of drought-resisting capacity and the establishment of assessment system for drought-resisting capacity (Figure 2).

(iii) Hydrological Regulation Effects of Regional Typical Artificial Vegetation. On the basis of experiment study system with the observation of field runoff plots, hydrological regulation effects and water conservation functions of typical artificial vegetation in different regions, such as interception of atmospheric precipitation, the conservation of soil water, and the decrease in runoff and soil erosion together with sediment transfer, should be studied, to clear the role of regional typical vegetation in hydrological regulation and water conservation and the differences between different vegetation as well (Figure 2).

(iv) Synthesized Attributes of Water Use by Regional Typical Artificial Vegetation. Targeting regional typical artificial vegetation, a structure model of the synthesized attributes of water use should be established, together with the introduction of synthesized assessment methods, to systematically analyze the synthesized attributes of typical artificial vegetation in such three aspects as water consumption from transpiration, water saving and drought resistance, and hydrological regulation, to further reveal the total strength of impacts of regional typical artificial vegetation on ecoenvironment through water use and the differences in such strength between different vegetation in a comprehensive way (Figure 2).

\section{Conflict of Interests}

There is no conflict of interests regarding the publication of the paper.

\section{Acknowledgments}

The authors would like to thank the National Natural Science Foundation of China (nos. 31270751 and 31160155), the 
National Science and Technology Program for Water Pollution Control and Treatment of China (no. 2012ZX07102-003), and the Program for Cultivating Young and Middle-aged Key Teachers of Yunnan University, China (no. XT412003), for financially supporting this work. The authors also appreciated the assistance of Professor Xue-Hua Wang from Southwest Forestry University, China, Professor Ming-Chun Peng from Yunnan University, China, Professors Song-Bai Song and Guang-Jun Zhang from Northwest Agriculture and Forestry University, China, and Professors Xing-min Mu, Zhan-li Wang, and Yong-Qing Ma from the Institute of Soil and Water Conservation, Chinese Academy of Sciences \& Ministry of Water Resources of China, with the preparation of the revised paper. The authors acknowledge the constructive comments and suggestions from the anonymous reviewers.

\section{References}

[1] J. Qiu, "China drought highlights future climate threats," Nature, vol. 465, no. 7295, pp. 142-143, 2010.

[2] R. Stone, "Severe drought puts spotlight on Chinese dams," Science, vol. 327, no. 5971, p. 1311, 2010.

[3] J. G. Liu, J. H. Wan, X. M. Tan, J. M. Ma, and N. Q. Zhang, "Drought in southwest China from autumn 2009 to spring 2010 and its comparative analysis with historical drought events," Journal of Disaster Prevention and Mitigation Engineering, vol. 31, no. 2, pp. 196-200, 2011 (Chinese).

[4] X. H. Huang, X. Y. Li, X. M. Mu et al., "The severe drought occurred in Southwest China in 2010: an examination from perspective of ecology," Soil and Water Conservation Research, vol. 20, no. 4, pp. 282-287, 2013 (Chinese).

[5] Y. Y. Du, "Did "barren green desert" boost the severe drought in Southwest China?" China Economic Times, p. A3, 1st April 2010, section A (Chinese).

[6] H. Y. Zhang, "The severe drought in Southwest China is a human disaster rather than a natural disaster," Science Times, p. A2, 13th April 2010, section A (Chinese).

[7] W. J. Zhang, "Did Eucalyptus contribute to environment degradation? Implications from a dispute on causes of severe drought in Yunnan and Guizhou, China," Environmental Skeptics and Critics, vol. 1, no. 2, pp. 34-38, 2012.

[8] F. K. Yu, X. H. Huang, Q. B. Liang et al., "Ecological water demand of regional vegetation: the example of the 2010 severe drought in Southwest China," Plant Biosystems, 2013.

[9] N. Robinson, R. J. Harper, and K. R. J. Smettem, "Soil water depletion by Eucalyptus spp. integrated into dryland agricultural systems," Plant and Soil, vol. 286, no. 1-2, pp. 141-151, 2006.

[10] J. C. Yang, J. H. Huang, Q. M. Pan, J. W. Tang, and X. G. Han, "Long-term impacts of land-use change on dynamics of tropical soil carbon and nitrogen pools," Journal of Environmental Sciences, vol. 16, no. 2, pp. 256-261, 2004.

[11] X. Q. Zhao, C. L. He, and Q. Yi, "Soil moisture and water conservation in Eucalyptus uraphylla spp. introduction mountain area," Journal of Soil and Water Conservation, vol. 26, no. 3, pp. 205-210, 2012 (Chinese).

[12] H. B. Hu, W. J. Liu, and M. Cao, "Impact of land use and land cover changes on ecosystem services in Menglun, Xishuangbanna, Southwest China," Environmental Monitoring and Assessment, vol. 146, no. 1-3, pp. 147-156, 2008.

[13] H. M. Li, T. M. Aide, Y. X. Ma, W. J. Liu, and M. Cao, "Demand for rubber is causing the loss of high diversity rain forest in SW
China," Biodiversity and Conservation, vol. 16, no. 6, pp. 17311745, 2007.

[14] F. J. Espinosa-García, E. Martínez-Hernández, and A. QuirozFlores, "Allelopathic potential of Eucalyptus spp plantations on germination and early growth of annual crops," Allelopathy Journal, vol. 21, no. 1, pp. 25-37, 2008.

[15] X. Sui, J. Zhang, X. Zhou, Q. Lu, T. Wang, and Q. Wang, "Transpiration characteristics of major shrub species for soil conservation on the Loess Plateau in western Shanxi Province, northern China," Journal of Beijing Forestry University, vol. 32, no. 6, pp. 20-26, 2010 (Chinese).

[16] H. Xu, X. M. Zhang, H. L. Yan, H. Y. Sun, and L. S. Shan, "Water consumption and transpiration of Haloxylon ammodendron in hinterland of Taklimakan desert," Acta Ecologica Sinica, vol. 28, no. 8, pp. 3713-3720, 2008 (Chinese).

[17] H. Wang, Z. Y. Ouyang, Y. F. Ren, and F. Y. Gao, “The characteristics of Magnolia liliflora transpiration and its impacting factors in Beijing City," Shengtai Xuebao, vol. 31, no. 7, pp. 1867-1876, 2011 (Chinese).

[18] Y. F. Wang, H. Y. Cai, J. P. Li, and Z. G. Chen, "Relationship between soil moisture and transpirational water-consumption of flue cured tobacco under different water supplying conditions," Transactions of the Chinese Society of Agricultural Engineering, vol. 23, no. 1, pp. 19-23, 2007 (Chinese).

[19] K. Zhang, X. Yin, X. Liu, and F. Wang, "Effects of sandcovering on apple trees transpiration and fruit quality in dry land orchards of Longdong, Gansu," Chinese Journal of Applied Ecology, vol. 21, no. 11, pp. 2755-2762, 2010 (Chinese).

[20] L. S. Shan, Y. Li, X. M. Zhang, and H. Wang, "Research on water consumption characteristics of Calligonumarborescens under different irrigation amount," Journal of Natural Resources, vol. 27, no. 3, pp. 440-449, 2012 (Chinese).

[21] Y. T. Zhang, F. C. Liang, S. L. Chang, Q. D. Shi, X. Li, and J. J. $\mathrm{Lu}$, "Scaling up for transpiration of Pinaceae schrenkiana stands based on $8 \mathrm{hm}^{2}$ permanent plots in Tianshan Mountains," Acta Ecologica Sinica, vol. 31, no. 12, pp. 3330-3339, 2011 (Chinese).

[22] H. Komatsu, E. Maita, and K. Otsuki, "A model to estimate annual forest evapotranspiration in Japan from mean annual temperature," Journal of Hydrology, vol. 348 , no. 3-4, pp. 330340, 2008.

[23] C. Tong, J. Z. Gong, R. Marrs, L. Zhang, and W. Q. Wang, "Pattern of transpiration of four shrub species and water consumption from shrub stands in an eco-reclamation catchment in Northwest China," Arid Land Research and Management, vol. 22, no. 3, pp. 242-254, 2008.

[24] E. A. Yepez, T. E. Huxman, D. D. Ignace et al., "Dynamics of transpiration and evaporation following a moisture pulse in semiarid grassland: a chamber-based isotope method for partitioning flux components," Agricultural and Forest Meteorology, vol. 132, no. 3-4, pp. 359-376, 2005.

[25] C.-Y. Xu and V. P. Singh, "Evaluation of three complementary relationship evapotranspiration models by water balance approach to estimate actual regional evapotranspiration in different climatic regions," Journal of Hydrology, vol. 308, no. 14, pp. 105-121, 2005.

[26] A. G. Duan, J. G. Zhang, J. P. Zhang, J. H. Wang, K. Li, and S. G. Zhang, "Studies on transpiration of seedlings of the tree species for vegetation restoration in the Dry-hot valleys of the Jinsha River," Forest Research, vol. 22, no. 1, pp. 55-62, 2009 (Chinese).

[27] L. Li, Z. Q. Jia, Y. J. Zhu, and Y. L. Qi, "Research advance on drought resistance mechanism of plant species in arid area of 
China," Journal of Desert Research, vol. 30, no. 5, pp. 1053-1059, 2010 (Chinese).

[28] X. Q. Fu, H. H. He, P. Wen, X. D. Luo, and J. K. Xie, "Drought resistance evaluation system for backcross lines of Dongxiang common wild rice (Oryza rufipogon Griff.)," Chinese Journal of Applied Ecology, vol. 23, no. 5, pp. 1277-1285, 2012 (Chinese).

[29] Z. M. Zhang, L. X. Dai, H. Ding et al., "Identification and evaluation of drought resistance in different peanut varieties widely grown in northern China," Acta Agronomica Sinica, vol. 38, no. 3, pp. 495-504, 2012 (Chinese).

[30] Z. H. Zhu, W. Y. Zheng, and X. K. Zhang, "Principal component analysis and comprehensive evaluation on morphological and agronomic traits of drought tolerance in rapeseed (Brassica napus L.)," Scientia Agricultura Sinica, vol. 44, no. 9, pp. 17751787, 2011 (Chinese).

[31] Z. Tian, F. Wang, W. Zhang, and X. Zhao, "Drought-resistance evaluation of marigold cultivars based on multiple statistics analysis," Chinese Journal of Applied Ecology, vol. 22, no. 12, pp. 3315-3320, 2011 (Chinese).

[32] S. S. Gill and N. Tuteja, "Reactive oxygen species and antioxidant machinery in abiotic stress tolerance in crop plants," Plant Physiology and Biochemistry, vol. 48, no. 12, pp. 909-930, 2010.

[33] S. V. Osipova, A. V. Permyakov, M. D. Permyakova, T. A. Pshenichnikova, and A. Börner, "Leaf dehydroascorbate reductase and catalase activity is associated with soil drought tolerance in bread wheat," Acta Physiologiae Plantarum, vol. 33, no. 6, pp. 2169-2177, 2011.

[34] P. Wang, H. Liu, H. Hua, L. Wang, and C. Song, "A vacuole localized $\beta$-glucosidase contributes to drought tolerance in Arabidopsis," Chinese Science Bulletin, vol. 56, no. 33, pp. 35383546, 2011.

[35] M. Faize, L. Burgos, L. Faize et al., "Involvement of cytosolic ascorbate peroxidase and $\mathrm{Cu} / \mathrm{Zn}$-superoxide dismutase for improved tolerance against drought stress," Journal of Experimental Botany, vol. 62, no. 8, pp. 2599-2613, 2011.

[36] A. Zézé, Y. C. Brou, A. Meddich, and F. Marty, "Molecular identification of MIP genes expressed in the roots of an arbuscularmycorrhizal Trifolium alexandrinum L. under water stress," African Journal of Agricultural Research, vol. 3, no. 1, pp. 78-83, 2008.

[37] J. J. Kang, S. M. Wang, and Z. H. Yang, "Effects of separate and mutual application of $\mathrm{Na}$ and $\mathrm{Si}$ on drought resistance of haloxglonammodengron," Journal of Desert Research, vol. 32, no. 3, pp. 793-800, 2012 (Chinese).

[38] K. Ikegami, M. Okamoto, M. Seo, and T. Koshiba, "Activation of abscisic acid biosynthesis in the leaves of Arabidopsis thaliana in response to water deficit," Journal of Plant Research, vol. 122, no. 2, pp. 235-243, 2009.

[39] Y. Luo, X. Zhao, R. Zhou, X. Zuo, J. Zhang, and Y. Li, "Physiological acclimation of two psammophytes to repeated soil drought and rewatering," Acta Physiologiae Plantarum, vol. 33, no. 1, pp. 79-91, 2011.

[40] J. Repková, M. Brestič, and K. Olšovská, "Leaf growth under temperature and light control," Plant, Soil and Environment, vol. 55, no. 12, pp. 551-557, 2009.

[41] R. Aroca, Plant Responses to Drought Stress, Springer, Berlin, Germany, 2012.

[42] M. Farooq, A. Wahid, N. Kobayashi, D. Fujita, and S. A. M. Basra, "Plant drought stress: effects, mechanisms and management," in Sustainable Agriculture, L. Eric, N. Mireille, D. Philippe, V. Souchere, and A. Caroline, Eds., pp. 153-188, Springer, Amsterdam, The Netherlands, 2009.
[43] E. A. Bray, "Molecular and physiological responses to waterdeficit stress," in Advances in Molecular Breeding Toward Drought and Salt Tolerant Crops, M. A. Jenks, P. M. Hasegawa, and S. M. Jain, Eds., pp. 121-140, Springer, Dordrecht, The Netherlands, 2007.

[44] M. Riera, C. Valon, F. Fenzi, J. Giraudat, and J. Leung, "The genetics of adaptive responses to drought stress: abscisic aciddependent and abscisic acid-independent signalling components," Physiologia Plantarum, vol. 123, no. 2, pp. 111-119, 2005.

[45] E. A. Bray, S. J. Bailey, and E. Weretilnyk, "Responses to abiotic stresses," in Biochemistry and Molecular Biology of Plants, B. Buchanan, W. Gruissem, and R. Jones, Eds., pp. 1158-1203, American Society of Plant Biologists, 2000.

[46] E. A. Bray, "Plant responses to water deficit," Trends in Plant Science, vol. 2, no. 2, pp. 48-54, 1997.

[47] M. Zivcak, H. M. Kalaji, H. B. Shao, K. Olsovska, and M. Brestic, "Photosynthetic proton and electron transport in wheat leaves under prolonged moderate drought stress," Journal of Photochemistry and Photobiology B: Biology, vol. 37, pp. 107-115, 2014.

[48] M. Zivcak, M. Brestic, Z. Balatova et al., "Photosynthetic electron transport and specific photoprotective responses in wheat leaves under drought stress," Photosynthesis Research, vol. 117, no. 1-3, pp. 529-546, 2013.

[49] M. Brestic, M. Zivcak, GR. Rout, and AB. Das, "PSII fluorescence techniques for measurement of drought and high temperature stress signal in plants: protocols and applications," in Molecular Stress Physiology of Plants, G. R. Rout and A. B. Das, Eds., pp. 87-131, Springer, Dordrecht, The Netherlands, 2013.

[50] K. Shinozaki and K. Yamaguchi-Shinozaki, "Gene expression and signal transduction in water-stress response," Plant Physiology, vol. 115, no. 2, pp. 327-334, 1997.

[51] W. J. Davies and J. Zhang, "Root signals and the regulation of growth and development of plants in drying soil," Annual Review of Plant Physiology and Plant Molecular Biology, vol. 42, no. 1, pp. 55-76, 1991.

[52] A. H. West and A. M. Stock, "Histidine kinases and response regulator proteins in two-component signaling systems," Trends in Biochemical Sciences, vol. 26, no. 6, pp. 369-376, 2001.

[53] A. Sharma and S. Komatsu, "Involvement of a $\mathrm{Ca}^{2+}$-dependent protein kinase component downstream to the gibberellinbinding phosphoprotein, RuBisCO activase, in rice," Biochemical and Biophysical Research Communications, vol. 290, no. 2, pp. 690-695, 2002.

[54] G. K. Agrawal, R. Rakwal, and H. Iwahashi, "Isolation of novel rice (Oryza sativa L.) multiple stress responsive MAP kinase gene, OsMSRMK2, whose mRNA accumulates rapidly in response to environmental cues," Biochemical and Biophysical Research Communications, vol. 294, no. 5, pp. 1009-1016, 2002.

[55] K. Shinozaki and K. Yamaguchi-Shinozaki, "Molecular responses to dehydration and low temperature: differences and cross-talk between two stress signaling pathways," Current Opinion in Plant Biology, vol. 3, no. 3, pp. 217-223, 2000.

[56] M. Pla, J. Gómez, A. Goday, and M. Pagès, "Regulation of the abscisic acid-responsive gene rab28 in maize viviparous mutants," Molecular and General Genetics, vol. 230, no. 3, pp. 394-400, 1991.

[57] M. Brestic, M. Zivcak, H. M. Kalaji, R. Carpentier, and S. I. Allakhverdiev, "Photosystem II thermostability in situ: environmentally induced acclimation and genotype-specific reactions in Triticum aestivum L," Plant Physiology and Biochemistry, vol. 57, pp. 93-105, 2012. 
[58] D. L. She, M. A. Shao, Y. F. Xue, and S. E. Yu, "Water conservation effects of slope land use pattern changes," Transactions of the CSAE, vol. 27, no. 4, pp. 22-27, 2011 (Chinese).

[59] D. L. She, M. A. Shao, L. C. Timm, I. P. SentíS, K. Reichardt, and S. E. Yu, "Impacts of land-use pattern on soil water-content variability on the loess plateau of China," Acta Agriculturae Scandinavica B: Soil \& Plant Science, vol. 60, no. 4, pp. 369-380, 2010.

[60] W. Hu, M. A. Shao, Q. J. Wang, J. Fan, and R. Horton, “Temporal changes of soil hydraulic properties under different land uses," Geoderma, vol. 149, no. 3-4, pp. 355-366, 2009.

[61] F. X. Tian, C. Y. Zhao, Z. D. Feng, S. Z. Peng, and H. H. Peng, "Eco-hydrological effects of Qinghai spruce (Picea crassifolia) canopy and its influence factors in the Qilian Mountains," Acta Ecologica Sinica, vol. 32, no. 4, pp. 1066-1076, 2012 (Chinese).

[62] Y. Q. Wang and Y. J. Wang, "Eco-hydrological function of typical forest ecosystems in three Gorges Reservoir area," Chinese Journal of Ecology, vol. 29, no. 10, pp. 1892-1900, 2010 (Chinese).

[63] D. G. Neary, G. G. Ice, and C. R. Jackson, "Linkages between forest soils and water quality and quantity," Forest Ecology and Management, vol. 258, no. 10, pp. 2269-2281, 2009.

[64] Y. P. Zhang, X. Wang, Y. J. Wang, W. J. Liu, and Y. H. Liu, "Comparison research on hydrological effect of the canopy of the tropical seasonal rainforest and rubber forest in Xishuangbanna, Yunnan," Acta Ecologica Sinica, vol. 23, no. 12, pp. 26532665, 2003 (Chinese).

[65] Z. H. Wang, C. Q. Duan, C. H. Wen, H. B. Wang, S. B. Zhang, and L. C. Qian, "Soil erosion and soil improvement of three artificial forest communities in middle Yunnan Province," Bulletin of Soil and Water Conservation, vol. 21, no. 2, pp. 23-27, 2001 (Chinese).

[66] J. Qi, Y. Zhang, Y. Liu et al., "Water-holding capacity of an evergreen broadleaf forest in Ailao Mountain and its functions in mitigating the effects of Southwest China drought," Acta Ecologica Sinica, vol. 32, no. 6, pp. 1692-1702, 2012 (Chinese).

[67] W. J. Liu, W. Y. Liu, H. J. Lu, W. P. Duan, and H. M. Li, "Runoff generation in small catchments under a native rain forest and a rubber plantation in Xishuangbanna, southwestern China," Water and Environment Journal, vol. 25, no. 1, pp. 138-147, 2011.

[68] X. Hou, C. Duan, C. Q. Tang, and D. Fu, "Nutrient relocation, hydrological functions, and soil chemistry in plantations as compared to natural forests in central Yunnan, China," Ecological Research, vol. 25, no. 1, pp. 139-148, 2010.

[69] W. J. Liu, W. Y. Liu, J. T. Li, Z. W. Wu, and H. M. Li, "Isotope variations of throughfall, stemflow and soil water in a tropical rain forest and a rubber plantation in Xishuangbanna, SW China," Hydrology Research, vol. 39, no. 5-6, pp. 437-449, 2008.

[70] X. H. Huang, H. Yuan, F. K. Yu et al., "Spatial-temporal succession of the vegetation in Xishuangbanna, China during 19762010: a case study based on RS technology and implications for eco-restoration," Ecological Engineering, vol. 70, pp. 255-262, 2014. 

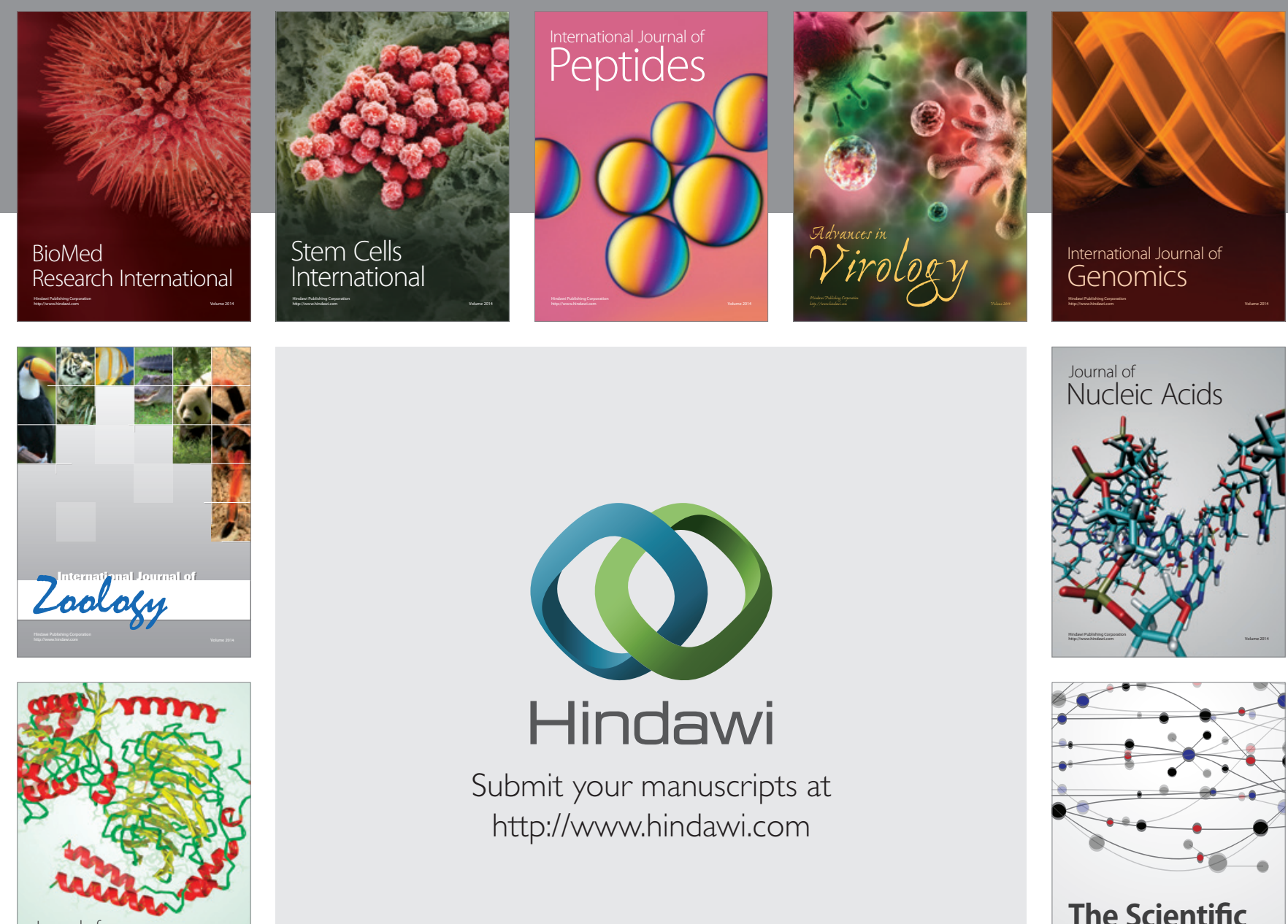

Submit your manuscripts at

http://www.hindawi.com

Journal of
Signal Transduction
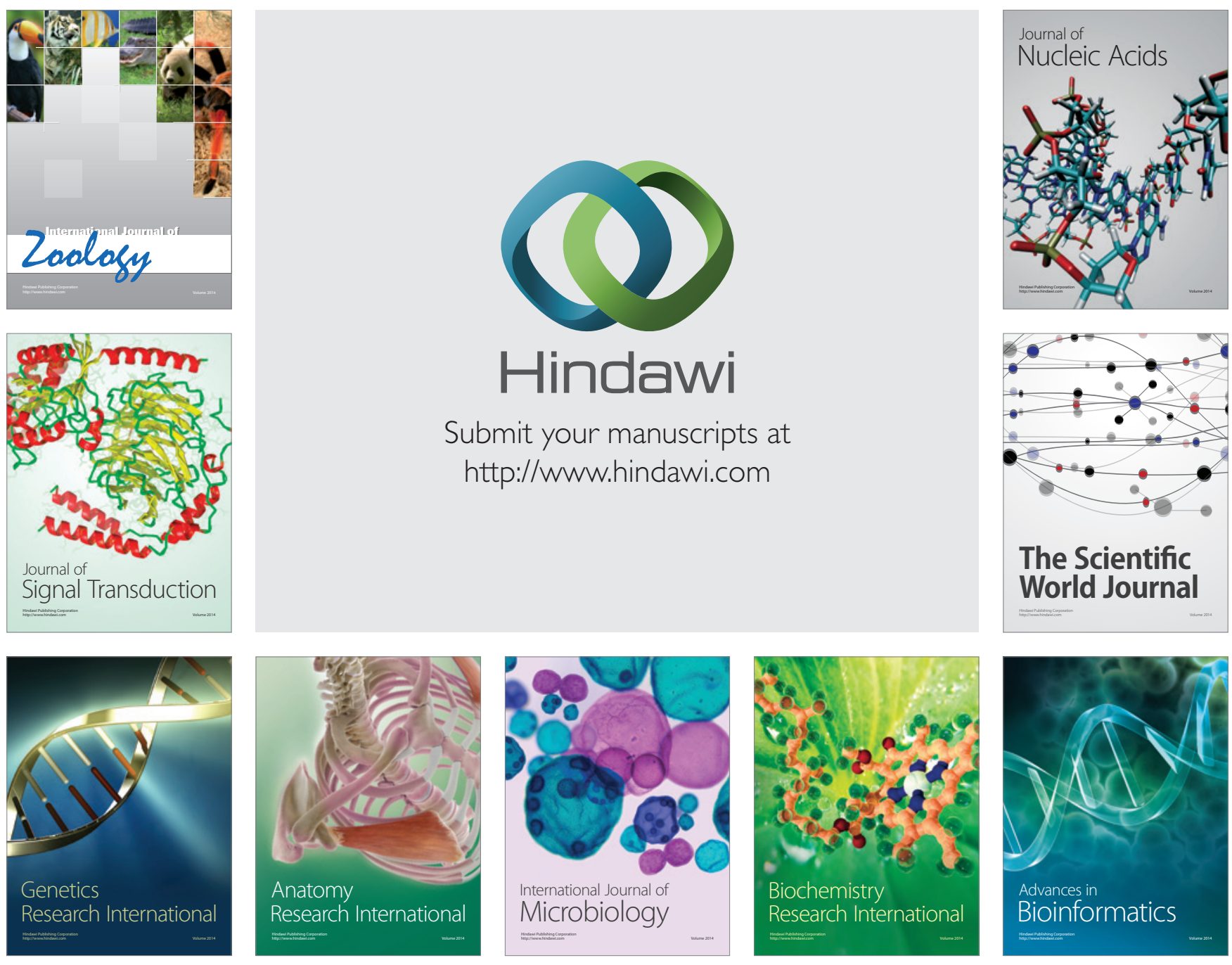

The Scientific World Journal
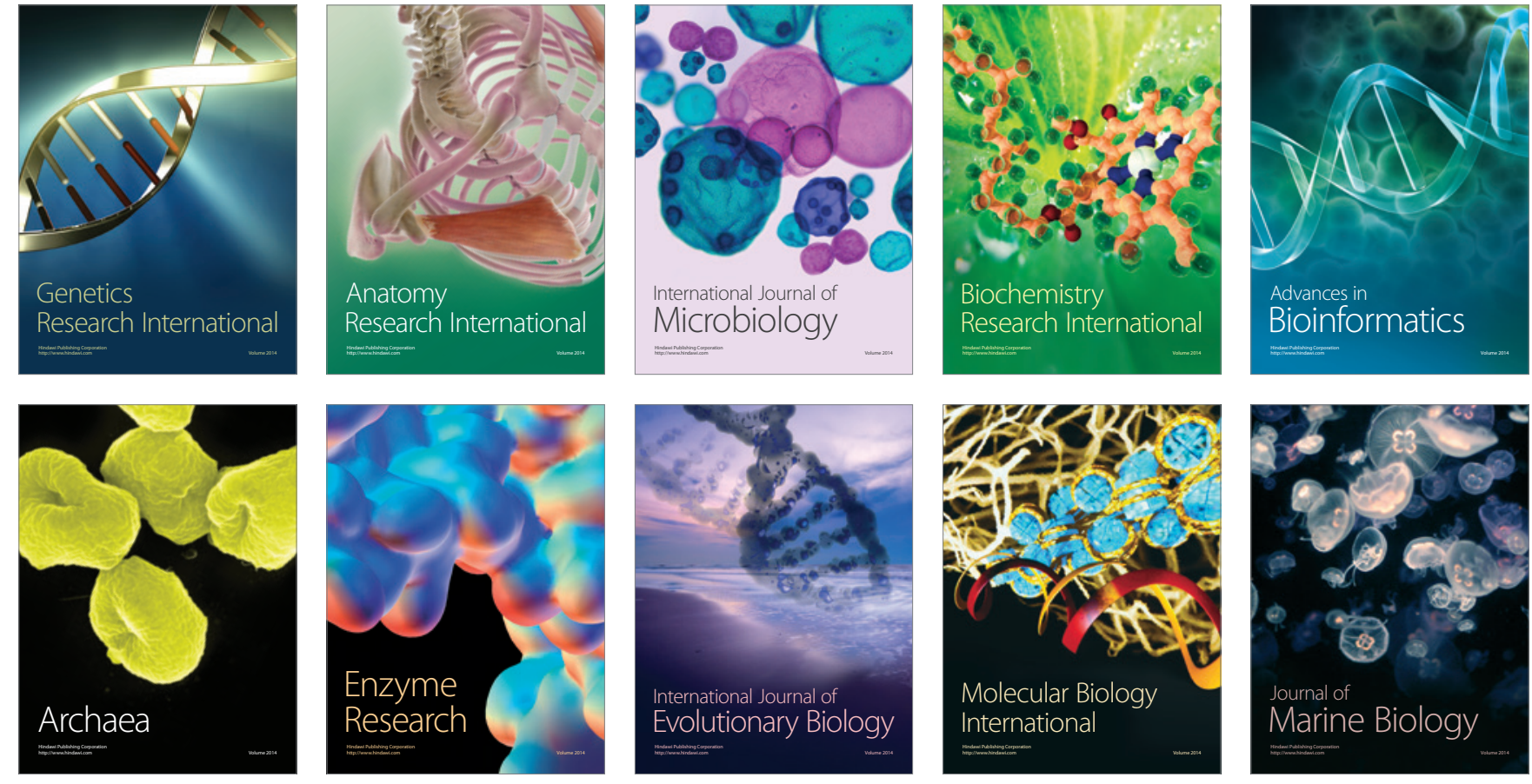